\title{
Pengaruh Disiplin Belajar terhadap Hasil Belajar Bahasa Indonesia Di Sekolah Dasar
}

\author{
Eka Selvi Handayani ${ }^{1}$, Hani Subakti ${ }^{2}$ \\ Universitas Widya Gama Mahakam Samarinda, Indonesia ${ }^{1,2}$ \\ Email: ekaselvi@uwgm.ac.id ${ }^{1} \underline{\text { hanisubakti@uwgm.ac.id }}^{2}$
}

\begin{abstract}
Abstrak
Disiplin belajar sangat berpengaruh terhadap hasil belajar siswa. Salah satu faktor yang mempengaruhi hasil belajar adalah disiplin belajar. Penelitian ini terfokus pada disiplin belajar terhadap hasil belajar Bahasa Indonesia siswa kelas III SD Negeri 002 Sungai Pinang, karena Bahasa Indonesia merupakan ilmu yang pasti. Sehingga siswa cenderung tidak menyukai mata pelajaran Bahasa Indonesia dan hal ini dapat mempengaruhi hasil belajar siswa. Penelitian ini merupakan penelitian ex post facto, karena tidak ada kontrol terhadap variabel bebas dan peneliti tidak mengadakan pengaturan atau manipulasi terhadap variabel bebas. Pada penelitian ini terdiri atas dua variabel, yaitu satu variabel bebas dan satu variabel terikat. Variabel bebas dalam penelitian ini adalah disiplin belajar (X). Sedangkan variabel terikatnya adalah hasil belajar Bahasa Indonesia (Y). Untuk pengambilan sampel menggunakan teknik sampling jenuh. Berdasarkan hasil penelitian dan hasil analisis dapat diketahui dari hasil perhitungan uji hipotesis diperoleh $\mathrm{t}_{\text {hitung }}=9,906$ untuk variabel $(\mathrm{X})$ dan $(\mathrm{Y})$. Kemudian mencari $t_{\text {tabel }}$ dengan $\alpha=5 \%, d k=33-2=31$, sehingga $t_{\text {tabel }}$ sebesar 1,696 . Karena $t_{\text {hitung }}>t_{\text {tabel }}$ maka Ha diterima, jika Ha diterima maka terdapat pengaruh disiplin belajar terhadap hasil belajar Bahasa Indonesia siswa kelas III SD Negeri 002 Sungai Pinang Kota Samarinda.
\end{abstract}

Kata kunci: disiplin belajar, hasil belajar, Bahasa Indonesia

\section{Abstract}

Learning disciplines have a profound effect on students' learning outcomes. One of the factors that influences learning outcomes is learning discipline. This research focuses on learning disciplines on the results of learning Indonesian grade III students of SD Negeri 002 Sungai Pinang, because Indonesian is a definite science. So students tend to dislike Indonesian subjects and this can affect students' learning outcomes. This study is an ex post facto study, as there is no control over free variables and researchers do not conduct arrangements or manipulations of free variables. In this study consisted of two variables, namely one free variable and one bound variable. The free variable in this study is the learning discipline $(X)$. While the bound variable is the result of learning Indonesian (Y). For sampling using saturated sampling techniques. Based on the results of the study and the results of the analysis can be known from the results of the hypothesis test calculation obtained $t_{\text {count }}=9,906$ for variables $(X)$ and $(Y)$. Then look for $t_{\text {table }}$ with $\alpha=5 \%, d k=33-2=31$, so that $t_{\text {table }}$ is 1,696. Because $t_{\text {count }}>t_{\text {table }}$ then $\mathrm{Ha}$ is accepted, if accepted then there is a disciplinary influence on the results of learning Indonesian students grade III SD Negeri 002 Sungai Pinang Samarinda city.

Keywords: learning disciplines, learning outcomes, Indonesian

Copyright (c) 2021 Eka Selvi Handayani, Hani Subakti

$\triangle$ Corresponding author :

Address : Jalan Banggeris Gang 7 Nomor 30 RT 03 Samarinda

Email : hanisubakti@uwgm.ac.id

ISSN 2580-3735 (Media Cetak)

Phone : 085250192555

DOI : https://doi.org/10.31004/basicedu.v5i1.633 
152 Pengaruh Disiplin Belajar terhadap Hasil Belajar Bahasa Indonesia di Sekolah Dasar- Eka Selvi Handayani, Hani Subakti

DOI : https://doi.org/10.31004/basicedu.v5i1.633

\section{PENDAHULUAN}

Dewasa ini, pendidikan adalah usaha sadar dan terencana untuk mewujudkan suasana belajar dan proses pembelajaran. Sehingga siswa secara aktif mengembangkan potensi dirinya untuk memiliki kekuatan spiritual keagamaan, pengendalian diri, kepribadian, kecerdasan, akhlak mulia, serta keterampilan yang diperlukan dirinya, masyarakat, dan negara. Sebagaimana tertuang dalam Pasal 3 (UU RI No. 20 Tahun 2003 tentang Sisdiknas), pendidikan nasional berfungsi mengembangkan kemampuan serta membentuk karakter dan peradaban bangsa yang bermartabat dalam rangka mencerdaskan kehidupan bangsa. Tujuannya untuk mengembangkan potensi siswa agar menjadi manusia yang beriman dan bertakwa kepada Tuhan Yang Maha Esa, berakhlak mulia, sehat, berilmu, kreatif, mandiri, dan menjadi warga negara yang demokratis serta bertanggung jawab. Adapun dalam tujuan pembelajaran Bahasa Indonesia di sekolah yang termuat pada kurikulum 2013 untuk mata pelajaran Bahasa Indonesia, yaitu peserta didik diharapkan memiliki kemampuan di bidang kebahasaan khususnya Bahasa Indonesia (Arifin, 2019).

Bahasa Indonesia sangat penting dalam pendidikan karena Bahasa Indonesia berfungsi dalam kehidupan sehari-hari sebagai alat berpikir secara logis. Bahasa Indonesia merupakan salah satu mata pelajaran yang diajarkan dijenjang pendidikan sekolah dasar. Seperti yang diutarakan oleh (Firmansyah, 2015) bahwa Bahasa Indonesia merupakan salah satu dari berbagai mata pelajaran yang diajarkan mulai dari jenjang pendidikan dasar yang dibutuhkan dalam kehidupan. Bahasa
Indonesia juga digunakan sebagai sarana untuk mengasah kemampuan berpikir dan mengembangkan potensi diri pada siswa sekolah dasar. Terlebih lagi, dijenjang pendidikan sekolah dasar Bahasa Indonesia menjadi acuan dan tolok ukur peningkatan sumber daya manusia untuk dapat lebih baik (Jamilah, 2019).

Sumantri (2010: 122) menjelaskan bahwa disiplin belajar adalah kepatuhan dari semua siswa untuk melaksanakan kewajiban belajar secara sadar sehingga diperoleh perubahan pada dirinya, baik itu berupa pengetahuan, perbuatan maupun sikap baik yang baik. Dalam proses belajar mengajar disiplin belajar sangat diperlukan, karena bertujuan untuk menghindarkan siswa dari hal-hal yang dapat mengganggu proses belajar mengajar. Disiplin akan membuat siswa terlatih dan mempunyai kebiasaan melakukan tindakan yang baik serta dapat mengontrol setiap tindakannya sehingga siswa akan taat dan patuh terhadap guru dan tertib terhadap kegiatan belajar mengajar yang sedang berlangsung di kelas. Dengan demikian, siswa yang menaati guru dan peraturan di sekolah dengan baik, maka akan berdampak pada hasil belajar siswa. Hasil belajar yang baik diperoleh dari proses belajar yang baik pula.

Hasil belajar merupakan suatu perubahan yang diperoleh setelah mengalami proses belajar. Hasil belajar siswa dalam pelajaran Bahasa Indonesia masih bervariasi, ada yang memuaskan, sedang, dan kurang memuaskan. Mata pelajaran Bahasa Indonesia sering kali dianggap sulit, karena Bahasa Indonesia merupakan ilmu yang pasti. Sehingga siswa cenderung tidak menyukai mata 
pelajaran Bahasa Indonesia dan hal ini dapat mempengaruhi hasil belajar siswa itu sendiri.

Berdasarkan hasil observasi di kelas III SD Negeri 002 Sungai Pinang masih banyak siswa yang kurang disiplin dalam belajar, seperti datang terlambat, lupa mengerjakan PR, tidak mendengarkan saat guru menjelaskan, berbicara sendiri, tidak mau mengerjakan tugas yang diberikan oleh guru, bahkan membuat kegaduhan di dalam kelas. Sehingga hasil belajar siswa khususnya pada mata pelajaran Bahasa Indonesia kurang baik karena siswa tidak mau mendengarkan pelajaran yang diberikan oleh guru dan tidak mau mengerjakan tugas yang diberikan oleh guru. Hal ini merupakan tugas guru untuk memperbaiki sikap disiplin dalam belajar siswa. Sikap disiplin belajar siswa sangat penting dimiliki agar siswa terarah dan teratur dalam belajar. Siswa yang memiliki sikap disiplin dalam belajar akan menyadari bahwa belajar bukanlah suatu paksaan, melainkan suatu bentuk usaha dirinya dalam mencapai tujuan belajar dan hasil belajar yang baik.

\section{METODE}

Pendekatan dalam penelitian ini adalah pendekatan kuantitatif, yaitu dimana data yang diperoleh berkaitan dengan angka yang menyebabkan penggunaan teknik analisis statistik. Jenis penelitian ini ex post facto, yaitu penelitian yang variabel independennya merupakan peristiwa yang sudah terjadi. Sugiyono (2010: 7) mengatakan penelitian ex post facto merupakan suatu penelitian yang dilakukan untuk meneliti peristiwa yang telah terjadi dan kemudian mengarah ke belakang untuk mengetahui faktorfaktor yang dapat menimbulkan kejadian tersebut. Sukardi (2015: 165) penelitian ex post facto merupakan penelitian di mana variabel bebas telah terjadi ketika peneliti mulai dengan pengamatan variabel terikat dalam suatu penelitian.

Siregar (2013: 4) penelitian ex post facto adalah penelitian dengan melakukan penyelidikan secara empiris yang sistematik, di mana peneliti tidak mempunyai kontrol langsung terhadap variabel-variabel bebas (independent variables) karena fenomena sukar dimanipulasi. Berdasarkan pendapat para ahli di atas, dapat disimpulkan bahwa penelitian ex post facto adalah penelitian yang dilakukan untuk meneliti peristiwa yang sudah terjadi, dimana peneliti tidak dapat memanipulasi variabel bebas dan variabel terikatnya yang ada pada saat penelitian dilakukan serta bertujuan untuk mengetahui faktor-faktor yang dapat menimbulkan kejadian tersebut.

Penelitian ini meliputi dua variabel yaitu, satu variabel bebas dan satu variabel terikat. Variabel bebas dalam penelitian ini adalah disiplin belajar (X) sedangkan variabel terikatnya adalah hasil belajar Bahasa Indonesia (Y). Sesuai dengan judul penelitian ini yaitu untuk mengetahui pengaruh disiplin belajar terhadap hasil belajar Bahasa Indonesia siswa kelas III SD Negeri 002 Sungai Pinang Kota Samarinda, maka desain penelitian dapat digambarkan sebagai berikut. 
154 Pengaruh Disiplin Belajar terhadap Hasil Belajar Bahasa Indonesia di Sekolah Dasar- Eka Selvi Handayani, Hani Subakti

DOI : https://doi.org/10.31004/basicedu.v5i1.633

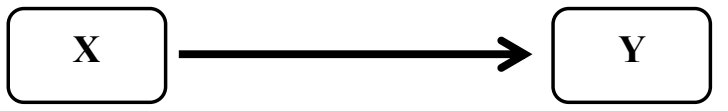

Gambar 1. Keterkaitan antara Variabel Bebas dan Variabel Terikat

(Sugiyono, 2018: 42)

Keterangan:

(X) : Disiplin belajar

(Y) : Hasil belajar Bahasa Indonesia

Penelitian dilaksanakan di SD Negeri 002 Sungai Pinang yang beralamat di Jalan Pelita Kelurahan Sungai Pinang Dalam, Kecamatan Sungai Kunjang, Kota Samarinda, Kalimantan Timur. Waktu penelitian ini dilakukan pada semester genap tahun pembelajaran 2019/2020. Sugiyono (2018: 80) menjelaskan bahwa populasi diartikan sebagai wilayah generalisasi yang terdiri atas objek/subjek yang mempunyai kualitas dan karakteristik tertentu yang ditetapkan oleh peneliti untuk dipelajari dan kemudian ditarik kesimpulannya. Populasi dalam penelitian ini adalah siswa kelas III SD Negeri 002 Sungai Pinang Samarinda tahun pembelajaran 2019/2020 yang berjumlah 33 siswa. Sugiyono (2018: 81) sampel adalah bagian dari jumlah dan karakteristik yang dimiliki oleh populasi tersebut. Teknik pengambilan sampel dalam penelitian ini adalah sampling jenuh. Sampling jenuh adalah teknik penentuan sampel bila semua anggota populasi digunakan sebagai sampel (Sugiyono, 2018: 85). Sampel untuk penelitian ini adalah siswa kelas III SD Negeri 002 Sungai Pinang Kota Samarinda yang berjumlah 33 siswa.

Validitas instrumen menunjukkan bahwa hasil dari suatu pengukuran menggambarkan segi atau aspek yang diukur. Uji validitas digunakan untuk mengetahui valid tidaknya angket. Untuk melakukan uji validitas angket, maka angket harus diuji cobakan terlebih dahulu. Pengujian dilakukan dengan mengorelasikan skor pada masing-masing item dengan skor totalnya. Perhitungan validitas dari sebuah instrumen dapat menggunakan rumus korelasi product moment atau yang dikenal dengan korelasi pearson dengan rumus:

$$
\mathrm{r}_{\mathrm{xy}}=\frac{N \sum X Y-\left(\sum X\right)\left(\sum Y\right)}{\sqrt{\left\{N \sum X^{2}-\left(\sum X\right)^{2}\right\}\left\{N \sum Y^{2}-\left(\sum Y\right)^{2}\right\}}}
$$

Keterangan:

$$
\begin{aligned}
& \mathrm{r}_{\mathrm{xy}}=\text { Angka indeks korelasi " } \mathrm{r} \text { " product moment } \\
& \mathrm{N}=\text { Jumlah sampel } \\
& \Sigma X Y=\text { Jumlah hasil perkalian antara skor butir } \mathrm{X} \\
& \quad \text { dan skor butir } \mathrm{Y} \\
& \Sigma X=\text { Jumlah seluruh skor butir } \mathrm{X} \\
& \Sigma Y=\text { Jumlah seluruh skor butir } \mathrm{Y}
\end{aligned}
$$

Sumber: (Sugiyono, 2007: 356)

Kriteria pengambilan keputusan dalam menentukan validitas butir adalah sebagai berikut. Jika $\mathrm{r}_{\text {hitung }}<\mathrm{r}_{\text {tabel}}$, maka butir dikatakan tidak valid. untuk memudahkan dalam menghitung validitas maka peneliti menggunakan program IBM SPSS versi 20.

Instrumen yang reliabel yaitu instrumen yang bila digunakan beberapa kali untuk mengukur objek yang sama, akan menghasilkan data yang sama. Artinya instrumen dikatakan reliabel apabila digunakan berkali-kali untuk mengukur tetap menghasilkan data yang sama. Pengujian reliabilitas dapat dilakukan dengan menggunakan rumus cronbach alpha. Suatu instrumen 
155 Pengaruh Disiplin Belajar terhadap Hasil Belajar Bahasa Indonesia di Sekolah Dasar- Eka Selvi Handayani, Hani Subakti

DOI : https://doi.org/10.31004/basicedu.v5i1.633

dinyatakan reliabel menurut Nunnally (Arifin, 2020: 34) jika nilai cronbach alpha $>0,70$.

$$
\mathrm{r}_{11}=\left(\frac{k}{k-1}\right)\left(1-\frac{\sum s_{t}^{2}}{s_{t}^{2}}\right)
$$

Keterangan:

$$
\begin{aligned}
& \mathrm{r}_{11}=\text { Koefisien reliabilitas instrumen } \\
& \mathrm{k}=\text { Jumlah butir pertanyaan } \\
& \Sigma S_{b}^{2}=\text { Jumlah varians butir pertanyaan } \\
& S_{t}^{2}=\text { Varians total }
\end{aligned}
$$

Sumber: (Sugiyono, 2007: 265)

Untuk memudahkan menghitung reliabilitas dalam instrumen menggunakan bantuan IBM SPSS versi 20.

Teknik pengumpulan data merupakan langkah yang paling utama dalam penelitian. Teknik pengumpulan data yang digunakan dalam penelitian ini yakni angket atau kuesioner, dokumentasi dan tes hasil belajar Bahasa Indonesia. Angket yang digunakan dalam penelitian ini berbentuk skala likert untuk mengukur sikap dengan pernyataan bersifat tertutup yaitu jawaban atas pernyataan yang diajukan sudah disediakan. Skala likert terdiri dari dua unsur yaitu pernyataan dan alternatif jawaban. Pernyataan ada dua bentuk yaitu pernyataan positif dan negatif, sedangkan alternatif jawaban terdiri dari: selalu, sering, kadang-kadang, dan tidak pernah (Asrul \& Rosnita, 2014: 106). Responden diminta untuk memilih kategori jawaban yang telah diatur oleh peneliti dengan memberikan tanda centang $(\sqrt{ })$ pada kolom yang tersedia. Angket ini digunakan untuk mengetahui disiplin belajar siswa.
Tabel 1. Penilaian Angket

\begin{tabular}{ccc}
\hline Jawaban & $\begin{array}{c}\text { Skor Pernyataan } \\
\text { Positif }\end{array}$ & $\begin{array}{c}\text { Skor Pernyataan } \\
\text { Negatif }\end{array}$ \\
\hline $\begin{array}{c}\text { Selalu } \\
\text { Sering }\end{array}$ & 4 & 1 \\
Kadang- & 3 & 2 \\
kadang & 2 & 3 \\
Tidak \\
Pernah
\end{tabular}

Instrumen penelitian ini menggunakan kuesinoner yang memiliki pilihan jawaban yang berjumlah 30 pertanyaan yang hasilnya menjadi data utama dalam penelitian ini. Dokumentasi pada penelitian ini sebagai data pendukung. Seperti data siswa untuk mengetahui jumlah siswa dan foto yang diambil saat penelitian dilakukan. Hal itu semakin memperkuat dan mendukung data yang ada. Tes adalah alat atau prosedur yang digunakan untuk mengetahui atau mengukur sesuatu dengan cara dan aturan-aturan yang sudah ditentukan (Hamzah, 2014: 100). Pengujian persyaratan analisis dilakukan apabila peneliti menggunakan analisis parametrik, maka harus dilakukan pengujian persyaratan analisis terhadap asumsiasumsinya, seperti normalitas dan linearitas untuk uji korelasi dan regresi. Teknik analisis data dalam penelitian ini menggunakan teknik analisis regresi linear sederhana, korelasi product moment, dengan bantuan SPSS versi 20.

Uji normalitas dilakukan untuk membantu ketepatan dalam melakukan uji hipotesis. Uji hipotesis hanya dapat dilakukan jika variabel yang akan dianalisis berdistribusi normal, maka dari itu diperlukan uji normalitas. Pada penelitian ini, pengujian normalitas data menggunakan uji 
kolmogorov-smirnov, dan diolah dengan IBM SPSS versi 20, digunakan rumus berikut.

$$
\mathrm{D}_{\max }=f \mathrm{o}(\mathrm{x})-\mathrm{Sn}(\mathrm{x})
$$

Keterangan:

$$
\begin{aligned}
f_{\mathrm{o}}(\mathrm{x})= & \text { Distribusi frekuensi kumulatif teoritis } \\
& \text { berdasarkan } \mathrm{H}_{0} \text { untuk setiap harga } \mathrm{x} \\
\mathrm{Sn}(\mathrm{x})= & \text { Distribusi frekuensi kumulatif dari } \mathrm{n} \\
& \text { pengamatan ( } \mathrm{n} \text { observasi) } \\
\mathrm{D}_{\max }= & \text { Deviasi (selisih) maksimum }
\end{aligned}
$$

Sumber: (Usman \& Akbar, 2009: 315)

Hipotesis untuk uji normalitas data dengan menggunakan uji kolmogorov-smirnov satu sampel adalah sebagai berikut.

$$
\begin{aligned}
& \mathrm{H}_{0} \text { : data berdistribusi normal } \\
& \mathrm{H}_{1} \text { : data tidak berdistribusi normal }
\end{aligned}
$$

Dengan taraf signifikasi $\alpha$ sebesar 0,05 atau $5 \%$ nilai $\mathrm{D}_{\max }$ dibandingkan dengan $\mathrm{D}_{\text {tabel. }}$ Kriteria pengujian hipotesis adalah $\mathrm{H}_{\mathrm{o}}$ diterima jika $\mathrm{D}_{\max } \leq$ $\mathrm{D}_{\text {tabel }}$ atau $\mathrm{p}>\alpha$, maka data berdistribusi normal.

Uji kolmogorov-smirnov dilakukan dengan IBM SPSS versi 20.

Uji homogenitas digunakan untuk mengetahui apakah data-data yang dianalisis bersifat homogen atau tidak. Untuk mengetahui varians yang homogen atau heterogen digunakan langkah-langkah pada uji fisher (Imaniyah, dkk., 2017: 21) sebagai berikut.

Menentukan taraf signifikan (a) untuk menguji hipotesis:

$\mathrm{H}_{0}: \boldsymbol{\sigma}_{12}=\boldsymbol{\sigma}_{22}$ (varians 1 sama dengan varians 2 atau homogen)

$\mathrm{H}_{1}: \boldsymbol{\sigma}_{12} \neq \boldsymbol{\sigma}_{22}$ (varians 1 tidak sama dengan varians 2 atau tidak homogen)
Dengan kriteria pengujian:

$$
\begin{aligned}
& \mathrm{H}_{0} \text { diterima jika } \boldsymbol{f}_{\text {hitung }}<\boldsymbol{f}_{\text {tabel }} \\
& \mathrm{H}_{1} \text { ditolak jika } \boldsymbol{f}_{\text {hitung }}>\boldsymbol{f}_{\text {tabel }}
\end{aligned}
$$

Menghitung varians tiap kelompok data

Tentukan nilai $\boldsymbol{f}_{\text {hitung }}$ yaitu:

$$
f_{\text {hitung }}=\frac{\text { varianst erbesar }}{\text { varians terkecil }}
$$

Tentukan $\boldsymbol{f}_{\text {tabel }}$ untuk taraf signifikansi $\alpha \mathrm{dk}$ $1=\mathrm{dk}$ pembilang $=\mathrm{na}-1$, dan $\mathrm{dk} 2=\mathrm{dk}$ penyebut $=$ nb-1. Lakukan pengujian dengan membandingkan nilai $\boldsymbol{f}_{\text {hitung }}$ dan $\boldsymbol{f}_{\text {tabel }}$

\section{HASIL DAN PEMBAHASAN}

Penelitian dilaksanakan di SD Negeri 002 dengan jumlah 33 siswa menjadi sampel dalam penelitian ini. Pada saat penelitian data yang diperoleh dari angket disiplin belajar merupakan data variabel $(\mathrm{X})$ dan untuk mengetahui hasil belajar siswa. Sebelum instrumen digunakan dalam penelitian, terlebih dahulu instrumen penelitian dilakukan pengujian. Uji coba instrumen dilakukan untuk mengetahui apakah instrumen yang digunakan memenuhi kualitas yang baik atau tidak. Alat yang digunakan dalam pengujian instrumen meliputi uji validitas dan uji reabilitas. Uji Validitas instrumen dilakukan dengan cara menyebarkan data instrumen kepada 33 siswa. Uji validitas ini digunakan untuk mengetahui valid atau tidaknya butir-butir pernyataan pada instrumen angket. Ketentuan validasi instrumen diukur berdasarkan kriteria validitas yang menyatakan jika $r_{\text {hitung }}>r_{\text {tabel }}$ maka instrumen dinyatakan valid, tetapi jika $\mathrm{r}_{\text {hitung }}<\mathrm{r}_{\text {tabel }}$ maka instrumen dinyatakan tidak valid. Diketahui bahwa 
157 Pengaruh Disiplin Belajar terhadap Hasil Belajar Bahasa Indonesia di Sekolah Dasar- Eka Selvi Handayani, Hani Subakti

DOI : https://doi.org/10.31004/basicedu.v5i1.633

$\mathrm{r}_{\text {tabel }}$ menggunakan taraf signifikan $\alpha=0,05$ dengan $\mathrm{n}=33$, maka diperoleh $\mathrm{r}_{\text {tabel }}$ Sebesar 0,3440. Untuk mempermudah menguji validitas tiap butir pernyataan pada angket peneliti menggunakan IBM SPSS versi 20. Kemudian peneliti melakukan uji validitas di SD Negeri 002 Sungai Pinang.

Setelah uji validitas selesai, selanjutnya dilakukan adalah uji reliabilitas angket disiplin belajar. Uji reliabilitas adalah serangkaian pengukuran yang memiliki konsistensi bila pengukuran yang dilakukan dengan alat ukur itu dilakukan secara berulang. Uji reliabilitas dilakukan untuk mengetahui tingkat konsistensi jawaban tetap atau konsisten untuk diujikan kapan pun angket tersebut diberikan.

Uji reliabilitas dilakukan dengan tujuan melihat konsistensi angket kapan pun disajikan. Uji reliabilitas pada penelitian ini menggunakan IBM SPSS versi 20 dengan teknik analisis croanbach's alpha. Pada uji reliabilitas dasar pengambilan keputusan dinyatakan reliabel apabila nilai koefisien lebih besar dari croanbach's alpha yaitu 0,7. Berdasarkan nilai reliabilitas angket disiplin belajar diperoleh nilai $r_{\text {hitung }}=0,848$. Kemudian dibandingkan dengan nilai croanbach's alpha yaitu 0,7 maka hasil dari uji reliabilitas dinyatakan reliabel, sehingga angket disiplin belajar dapat digunakan.

Berdasarkan hasil perhitungan total skor terhadap angket penelitian tentang disiplin belajar siswa kelas III SD Negeri 002 Sungai Pinang Kota Samarinda, dapat dikemukakan bahwa perolehan skor tertinggi dari angket adalah sebesar 84 dan skor terendah adalah sebesar 47. Maka untuk memperjelas data disiplin belajar di atas akan ditunjukkan pada tabel distribusi frekuensi. Sebelum membuat tabel distribusi frekuensi, terlebih dahulu peneliti akan mencari range, banyak interval, dan banyak kelas. Maka selanjutnya disajikan ke dalam bentuk distribusi frekuensi.

a. $\quad$ Range $=$ data tertinggi-data terendah

$$
=84-47
$$$$
=37
$$

b. Banyak Kelas

$$
\begin{aligned}
\mathrm{BK} & =1+3,3 \log \mathrm{n} \\
& =1+3,3 \log 33 \\
& =1+3,3(1,519) \\
& =4,3(1,519) \\
& =6,5296 \approx 7
\end{aligned}
$$

c. Panjang Kelas

$$
\begin{aligned}
\mathrm{PK} & =\text { Range/ } \mathrm{BK} \\
& =37 / 7 \\
& =5,286 \approx 5 / 6
\end{aligned}
$$

\begin{tabular}{|c|c|c|c|c|c|c|c|}
\hline Skor & Bb & Ba & $f i$ & $x i$ & fi.xi & $x i^{2}$ & $f i . x i^{2}$ \\
\hline $47-52$ & 47 & 52 & 2 & 49.5 & 99 & 2450 & 4901 \\
\hline 53-58 & 53 & 58 & 0 & 55.5 & 0 & 3080 & 0 \\
\hline $59-64$ & 59 & 64 & 1 & 61.5 & 62 & 3782 & 3782 \\
\hline $65-70$ & 65 & 70 & 8 & 67.5 & 540 & 4556 & 36450 \\
\hline $71-76$ & 71 & 76 & 15 & 73.5 & 1103 & 5402 & 81034 \\
\hline 77-82 & 77 & 82 & 6 & 79.5 & 477 & 6320 & 37922 \\
\hline 83-88 & 83 & 88 & 1 & 85.5 & 86 & 7310 & 7310 \\
\hline \multicolumn{2}{|c|}{ Jumlah } & & 33 & & 2366 & 32902 & 171398 \\
\hline
\end{tabular}

Dari rumus di atas, maka dapat diketahui bahwa nilai range adalah 37 , banyak kelas adalah 7, dan panjang kelas adalah 6. Adapun distribusi frekuensi disiplin belajar dapat dilihat pada tabel berikut.

Tabel 2. Distribusi Frekuensi Disiplin Belajar 
158 Pengaruh Disiplin Belajar terhadap Hasil Belajar Bahasa Indonesia di Sekolah Dasar- Eka Selvi Handayani, Hani Subakti

DOI : https://doi.org/10.31004/basicedu.v5i1.633

Dari tabel distribusi frekuensi di atas, dapat dihitung:

a. Mean

$$
\begin{aligned}
\bar{X} & =\frac{\sum(f, x i)}{n} \\
& =\frac{2366}{33} \\
& =71,68
\end{aligned}
$$

b. Median

$$
\begin{aligned}
\mathrm{Me} & =B+\frac{\frac{n}{2}-F}{f} \times p \\
& =71-0,5+\frac{16,5-11}{15} \times 6 \\
& =70,5+2,2 \\
& =72,5
\end{aligned}
$$

c. Modus

$$
\begin{aligned}
\text { Mo } & =B+\frac{f 1}{f 1+f 2} \times p \\
& =71-0,5+\frac{7}{7+9} \times 6 \\
& =70,5+2,63 \\
& =73,13
\end{aligned}
$$

d. Varians

$$
\begin{aligned}
\mathrm{S}^{2} & =\frac{\sum f x^{2}-\frac{\left(\sum f x\right)^{2}}{\sum f}}{\sum f-1} \\
& =\frac{\sum f x^{2}-\frac{\left(\sum f x\right)^{2}}{\sum f}}{\sum f-1} \\
& =\frac{171398-\frac{(366)^{2}}{33}}{33-1} \\
& =\frac{171398-169563}{32} \\
& =57,34
\end{aligned}
$$

e. Standar Deviasi

\begin{tabular}{|c|c|c|c|}
\hline Kategori & Ketentuan & Frekuensi & Persentase \\
\hline $\begin{array}{l}\text { Sangat } \\
\text { Rendah }\end{array}$ & $X \leq 60,32$ & 2 & $6,1 \%$ \\
\hline Rendah & $\begin{array}{c}60,32<\mathrm{X} \leq \\
67,90\end{array}$ & 6 & $18,2 \%$ \\
\hline Sedang & $\begin{array}{c}67,90<X \leq \\
75,47\end{array}$ & 12 & $36,4 \%$ \\
\hline Tinggi & $\begin{array}{c}75,47<X \leq \\
83,04\end{array}$ & 12 & $36,4 \%$ \\
\hline $\begin{array}{l}\text { Sangat } \\
\text { Tinggi }\end{array}$ & $83,04<\mathrm{X}$ & 1 & $3 \%$ \\
\hline \multicolumn{2}{|c|}{ Jumlah } & 33 & $100 \%$ \\
\hline
\end{tabular}

$$
\begin{aligned}
S & =\sqrt{S^{2}} \\
& =\sqrt{57,34} \\
& =7,57
\end{aligned}
$$

Dari perhitungan di atas, dapat diketahui nilai rata-rata (mean) skor disiplin belajar sebesar 71,68 , nilai median atau nilai tengah adalah 72,5 , nilai modus atau perkiraan data yang sering muncul (modus) adalah 73,13, varians adalah 57,34, dan standar deviasi adalah 7,57. Berdasarkan ketentuan tabel konversi skor aktual menjadi nilai skala lima, maka dapat diadakan perhitungan konversi skor aktual menggunakan nilai skala lima pada variabel disiplin belajar (X). Untuk lebih lengkapnya dapat dilihat dari tabel di bawah ini.

Tabel 3. Konversi Skor Aktual Menjadi Nilai Skala Lima Variabel Disiplin Belajar

Dengan demikian, dapat dikemukakan bahwa kategori variabel disiplin belajar adalah sebanyak 2 responden $(6,1 \%)$ berada pada kategori sangat rendah, sebanyak 6 responden $(18,2 \%)$ berada pada kategori rendah sebanyak 12 responden $(36,4 \%)$ berada pada kategori sedang, sebanyak 12 responden $(36,4 \%)$ berada pada kategori tinggi, dan selebihnya sebanyak 1 responden (3) berada pada kategori sedang. Berdasarkan hasil perhitungan data tersebut dapat 
159 Pengaruh Disiplin Belajar terhadap Hasil Belajar Bahasa Indonesia di Sekolah Dasar- Eka Selvi Handayani, Hani Subakti

DOI : https://doi.org/10.31004/basicedu.v5i1.633

diketahui bahwa nilai rata-rata (mean) dari variabel disiplin belajar sebesar 71,68 dalam konversi skor aktual menggunakan nilai skala lima berada pada ketentuan $67,90<X \leq 75,47$ yang berarti bahwa disiplin belajar siswa SD Negeri 002 Sungai Pinang tergolong kategori sedang.

Berdasarkan hasil belajar siswa kelas III SD Negeri 002 Sungai Pinang Samarinda, dapat dikemukakan bahwa perolehan skor tertinggi dari nilai ulangan harian Bahasa Indonesia adalah sebesar 85 dan skor terendah adalah sebesar 60 . Maka untuk memperjelas data hasil belajar di atas akan ditunjukkan pada tabel distribusi frekuensi. Sebelum membuat tabel distribusi frekuensi, terlebih dahulu peneliti akan mencari range, banyak interval, dan banyak kelas. Maka selanjutnya disajikan ke dalam bentuk distribusi frekuensi.

a. Range = data tertinggi- data terendah

$$
\begin{aligned}
& =85-60 \\
& =25
\end{aligned}
$$

b. Banyak Kelas

$$
\begin{aligned}
\mathrm{BK} & =1+3,3 \log \mathrm{n} \\
& =1+3,3 \log 33 \\
& =1+3,3(1,519) \\
& =4,3(1,519) \\
& =6,5296 \approx 7
\end{aligned}
$$

c. Panjang Kelas

$$
\begin{aligned}
\mathrm{PK} & =\text { Range/ } \mathrm{BK} \\
& =25 / 7 \\
& =3,57 \approx 4
\end{aligned}
$$

\begin{tabular}{|c|c|c|c|c|c|c|c|}
\hline Skor & $\begin{array}{l}\text { B } \\
\mathbf{b}\end{array}$ & B & $f i$ & $x i$ & fi.xi & $x i^{2}$ & $\begin{array}{c}f i . x \\
i^{2}\end{array}$ \\
\hline $60-63$ & 60 & 6 & 2 & 61.5 & 123 & $\begin{array}{c}378 \\
2\end{array}$ & $\begin{array}{c}756 \\
5\end{array}$ \\
\hline 64-67 & 64 & $\begin{array}{l}6 \\
7\end{array}$ & 0 & 65.5 & 0 & $\begin{array}{c}429 \\
0\end{array}$ & 0 \\
\hline 68-71 & 68 & 7 & 11 & 69.5 & 765 & $\begin{array}{c}483 \\
0\end{array}$ & $\begin{array}{c}531 \\
33\end{array}$ \\
\hline 72-75 & 72 & $\begin{array}{l}7 \\
5\end{array}$ & 10 & 73.5 & 735 & $\begin{array}{c}540 \\
2\end{array}$ & $\begin{array}{c}540 \\
23\end{array}$ \\
\hline 76-79 & 76 & 7 & 0 & 77.5 & 0 & $\begin{array}{c}600 \\
6\end{array}$ & 0 \\
\hline $80-83$ & 80 & 8 & 7 & 81.5 & 571 & $\begin{array}{c}664 \\
2\end{array}$ & $\begin{array}{c}464 \\
96\end{array}$ \\
\hline 84-87 & 84 & 8 & 3 & 85.5 & 257 & $\begin{array}{c}731 \\
0\end{array}$ & $\begin{array}{c}219 \\
31\end{array}$ \\
\hline $\begin{array}{c}\text { Juml } \\
\text { ah }\end{array}$ & 33 & & $\begin{array}{c}245 \\
0\end{array}$ & $\begin{array}{c}3826 \\
4\end{array}$ & $\begin{array}{c}1831 \\
46\end{array}$ & & \\
\hline
\end{tabular}

Dari rumus di atas, maka dapat diketahui bahwa nilai range adalah 25 , banyak kelas adalah 7, dan panjang kelas adalah 4. Adapun distribusi frekuensi disiplin belajar dapat dilihat pada tabel berikut.

Tabel 4. Distribusi Frekuensi Disiplin Belajar

Dari tabel distribusi frekuensi di atas, dapat dihitung:

a. Mean

$$
\begin{aligned}
\bar{X} & =\frac{\sum(f . x i)}{n} \\
& =\frac{2450}{33} \\
& =74,23
\end{aligned}
$$

b. Median

$$
\begin{aligned}
& \mathrm{Me}=B+\frac{\frac{n}{2}-F}{f} \times p \\
& =72-0,5+\frac{16,5-13}{10} \times 4 \\
& =71,5+1,4 \\
& =72,9
\end{aligned}
$$

c. Modus

$$
\begin{aligned}
\text { Mo } & =B+\frac{f 1}{f 1+f 2} \times p \\
& =72-0,5+\frac{-1}{-1+10} \times 4 \\
& =71,5+(-0,45)
\end{aligned}
$$


160 Pengaruh Disiplin Belajar terhadap Hasil Belajar Bahasa Indonesia di Sekolah Dasar- Eka Selvi Handayani, Hani Subakti

DOI : https://doi.org/10.31004/basicedu.v5i1.633

$$
=71,06
$$

d. Varians

$$
\begin{aligned}
S^{2} & =\frac{\sum f x^{2}-\frac{\left(\sum f x\right)^{2}}{\sum f}}{\sum f-1} \\
& =\frac{\sum f x^{2}-\frac{(\Sigma f x)^{2}}{\sum f}}{\sum f-1} \\
& =\frac{183146-\frac{(2450)^{2}}{3}}{33-1} \\
& =\frac{183146-181820}{32} \\
& =41,45
\end{aligned}
$$

e. Standar Deviasi

$$
\begin{aligned}
S & =\sqrt{S^{2}} \\
& =\sqrt{41,45} \\
& =6,44
\end{aligned}
$$

Dari perhitungan di atas, dapat diketahui nilai rata-rata (mean) skor hasil belajar sebesar 74,23 , nilai median atau nilai tengah adalah 72,9 , nilai modus atau perkiraan data yang sering muncul (modus) adalah 71,06, varians adalah 41,45, dan standar deviasi adalah 6,44. Berdasarkan ketentuan tabel konversi skor aktual menjadi nilai skala lima, maka dapat diadakan perhitungan konversi skor aktual menggunakan nilai skala lima pada variabel hasil belajar $(\mathrm{Y})$. Untuk lebih lengkapnya dapat dilihat dari tabel di bawah ini.

Tabel 5. Konversi Skor Aktual Menjadi Nilai Skala Lima Variabel Hasil Belajar

\begin{tabular}{cccc}
\hline Kategori & Ketentuan & Frekuensi & Persentase \\
\hline $\begin{array}{c}\text { Sangat } \\
\text { Rendah }\end{array}$ & $\mathrm{X} \leq 64,57$ & 2 & $6,1 \%$ \\
Rendah & $\begin{array}{c}64,57<\mathrm{X} \\
\leq 71,01\end{array}$ & 11 & $33,3 \%$ \\
Sedang & $\begin{array}{c}71,01<\mathrm{X} \\
\mathrm{H}\end{array}$ & 10 & $30,3 \%$ \\
\hline
\end{tabular}

\begin{tabular}{cccc}
\hline Tinggi & $\begin{array}{c}\leq 77,45 \\
77,45<\mathrm{X} \\
\leq 83,89\end{array}$ & 7 & $21,2 \%$ \\
\hline $\begin{array}{c}\text { Sangat } \\
\text { Tinggi }\end{array}$ & $83,89<\mathrm{X}$ & 3 & $9,1 \%$ \\
\hline Jumlah & 33 & $100 \%$ & \\
\hline
\end{tabular}

Dengan demikian, dapat dikemukakan bahwa kategori variabel hasil belajar adalah sebanyak 2 responden $(6,1 \%)$ berada pada kategori sangat rendah, sebanyak 11 responden $(33,3 \%)$ berada pada kategori rendah sebanyak 10 responden $(30,3 \%)$ berada pada kategori sedang, sebanyak 7 responden $(21,2 \%)$ berada pada kategori tinggi, dan selebihnya sebanyak 3 responden $(9,1 \%)$ berada pada kategori sangat tinggi. Berdasarkan hasil perhitungan data tersebut dapat diketahui bahwa nilai rata-rata (mean) dari variabel hasil belajar sebesar 74,23 dalam konversi skor aktual menggunakan nilai skala lima berada pada ketentuan $71,01<\mathrm{X} \leq 77,45$ yang berarti bahwa disiplin belajar siswa SD Negeri 002 Sungai Pinang tergolong kategori sedang.

Uji normalitas adalah sebuah uji yang dilakukan dengan tujuan untuk mengetahui apakah sebaran data pada sebuah kelompok data berdistribusi normal atau tidak. Uji normalitas berfungsi untuk mengukur data nominal, ordinal, interval maupun rasio. Jika sebaran data berdistribusi normal maka analisis menggunakan metode parametrik, sedangkan jika sebaran data tidak berdistribusi normal maka analisis menggunakan metode non parametrik.

Hipotesis uji normalitas data dengan menggunakan uji kolmogorov-smirnov yaitu:

$\mathrm{H}_{0}$ : Data berdistribusi normal

$\mathrm{H}_{1}$ : Data tidak berdistribusi normal 
161 Pengaruh Disiplin Belajar terhadap Hasil Belajar Bahasa Indonesia di Sekolah Dasar- Eka Selvi Handayani, Hani Subakti

DOI : https://doi.org/10.31004/basicedu.v5i1.633

Dengan taraf signifikasi $\alpha$ sebesar 0,05 atau $5 \%$ nilai $\mathrm{D}_{\max }$

Jika dibandingkan dengan $\mathrm{D}_{\text {tabel }}$ maka kriteria pengujian hipotesis adalah $\mathrm{H}_{0}$ diterima jika $\mathrm{D}_{\max } \leq \mathrm{D}_{\text {tabel }}$ atau $\mathrm{p}>\alpha$. Berdasarkan hasil uji normalitas menggunakan IBM SPSS versi 20, nilai signifikansi sebesar $0,973>$ taraf signifikan 0,05 maka dapat disimpulkan $\mathrm{H}_{0}$ diterima, sebaran data berdistribusi normal.

Uji homogenitas dilakukan untuk mengetahi data yang diambil dari lapangan bersifat homogen atau tidak. Pada penelitian ini peneliti menggunakan uji fisher dengan bantuan Ms. Excel 2010. Hipotesis untuk menentukan taraf signifikan $(\alpha)$ yaitu:

$\mathrm{H}_{0}: \boldsymbol{\sigma}_{12}=\boldsymbol{\sigma}_{22}$ (varians 1 sama dengan varians 2 atau homogen)

$\mathrm{H}_{1}: \boldsymbol{\sigma}_{12} \neq \boldsymbol{\sigma}_{22}$ (varians 1 tidak sama dengan varians 2 atau tidak homogen)

Adapun penarikan kesimpulannya:

$$
\begin{aligned}
& \mathrm{H}_{0} \text { : Diterima jika } \boldsymbol{f}_{\text {hitung }}<\boldsymbol{f}_{\text {tabel }} \\
& \mathrm{H}_{1} \text { : Ditolak jika } \boldsymbol{f}_{\text {hitung }}>\boldsymbol{f}_{\text {tabel }}
\end{aligned}
$$

Setelah melakukan perhitungan diperoleh varians terbesar dan varians terkecil. Varians terbesar 65,148 dan varians terkecil 37,121 kemudian mencari $\boldsymbol{f}_{\text {hitung yaitu sebagai berikut. }}$

$$
\begin{aligned}
f_{\text {hitung }}= & \frac{\text { varianst terbesar }}{\text { varians t erkecil }} \\
= & \frac{65,148}{37,121} \\
= & 1,755
\end{aligned}
$$

Diperoleh hasil sebesar 1,755 selanjutnya mencari $f_{\text {tabel }}$ dengan signifikan $\boldsymbol{\alpha}, d k 1=d k$ pembilang $=$ na- 1 , dan $d k 2=d k$ penyebut $=$ nb- 1 maka diperoleh $f_{\text {tabel }}$ sebesar 1,804 . Selanjutnya dari hasil $f_{\text {hitung }} 1,755$ dibandingkan dengan $f_{\text {tabel }}$ yaitu 1,804 sehingga data dinyatakan homogen karena hasil $\boldsymbol{f}_{\text {hitung }} 1,755<1,804$.

Penelitian ini bertujuan untuk mencari pengaruh disiplin belajar terhadap hasil belajar Bahasa Indonesia siswa kelas III SD Negeri 002 Sungai Pinang Samarinda. Berdasarkan hasil perhitungan uji normalitas menggunakan IBM SPSS versi 20 diperoleh nilai signifikansi sebesar 0,973 > taraf signifikan 0,05 maka sebaran data berdistribusi normal. Kemudian dilakukan perhitungan homogenitas menggunakan uji fisher dengan bantuan Ms. Excel sehingga mendapatkan nilai varians terbesar 65,148 sedangkan nilai terkecil sebesar 37,121 . Selanjutnya hasil $f_{\text {hitung }}$ dibandingkan dengan $\boldsymbol{f}_{\text {tabel }}$ ditunjukkan oleh nilai $\boldsymbol{f}_{\text {hitung }}<\boldsymbol{f}_{\text {tabel }}$ atau $1,755<1,804$ sehingga data $\mathrm{H}_{0}$ dinyatakan diterima, maka data analisis bersifat homogen.

Kemudian dilakukan perhitungan menggunakan konversi skor aktual menjadi nilai skala lima pada nilai rata-rata (mean) dari variabel disiplin belajar sebesar 71,68 dalam konversi skor aktual berada pada ketentuan $67,90<\mathrm{X} \leq 75,47$ yang berarti bahwa disiplin belajar siswa SD Negeri 002 Sungai Pinang tergolong kategori sedang, sedangkan nilai rata-rata (mean) dari variabel hasil belajar sebesar 74,23 dalam konversi skor aktual menggunakan nilai skala lima berada pada ketentuan $71,01<\mathrm{X} \leq 77,45$ yang berarti bahwa disiplin belajar siswa SD Negeri 002 Sungai Pinang tergolong kategori sedang. 
162 Pengaruh Disiplin Belajar terhadap Hasil Belajar Bahasa Indonesia di Sekolah Dasar- Eka Selvi Handayani, Hani Subakti

DOI : https://doi.org/10.31004/basicedu.v5i1.633

Selanjutnya adalah mencari persamaan regresi antara disiplin belajar dengan hasil belajar Bahasa Indonesia menggunakan perhitungan manual dan IBM SPSS versi 20. Hasil analisis persamaan regresi sederhananya $\hat{Y}=$ $26,956+0,658 x$, menunjukkan bahwa jika $x=0$ maka diperoleh nilai hasil belajar sebesar 26,956. Ini berarti apabila siswa tidak memiliki nilai disiplin belajar, maka hasil belajar tersebut mendapatkan nilai 26,956. Namun apabila nilai disiplin belajar $=5$ maka nilai rata-rata hasil belajar $\hat{Y}=26,956+0,658(5)=26,956+3,29=30,246$. Jadi dari persamaan regresi di atas dapat diperkirakan bahwa, bila nilai disiplin belajar bertambah 1 , maka nilai rata-rata hasil belajar bertambah 0,658. Dapat disimpulkan bahwa semakin tinggi disiplin belajar maka semakin tinggi pula hasil belajar.

Kemudian dilakukan penghitungan uji keberartian menggunakan IBM SPSS versi 20 di peroleh nilai $f_{\text {hitung }}=98,127$ kemudian mencari $f_{\text {tabel }}$ dengan $\alpha=5 \%, \mathrm{~V}_{1}=1$, dan $\mathrm{V}_{2}=\mathrm{n}-2=33-2=$ 31 , diperoleh $f_{\text {hitung }}=98,127>f_{\text {tabel }}=4,16$ maka dapat dinyatakan bahwa secara simultan terdapat keberartian disiplin belajar terhadap hasil belajar. Kemudian dilakukan penghitungan uji linearitas menggunakan IBM SPSS versi 20 diperoleh nilai $\boldsymbol{f}_{\text {hitung }}$ sebesar 1,886 dan didapatkan nilai $\boldsymbol{f}_{\text {tabel }}$ sebesar 2,52. Sehingga $f_{\text {hitung }}<f_{\text {tabel }}$ maka terdapat hubungan yang linear antara disiplin belajar dengan hasil belajar Bahasa Indonesia.

Selanjutnya dilakukan penghitungan nilai korelasi/hubungan antara disiplin belajar dengan hasil belajar Bahasa Indonesia menggunakan metode hitung manual dan IBM SPSS versi 20 diperoleh hasil yang sama menggunakan kedua metode tersebut yaitu 0,872 . Sehingga dapat disimpulkan bahwa nilai korelasi antara disiplin belajar terhadap hasil belajar dapat dikategorikan sangat kuat. Setelah diperoleh nilai korelasi/hubungan, dilakukan uji koefisien korelasi. Uji koefisien korelasi juga dilakukan menggunakan metode hitung manual dan menggunakan IBM SPSS versi 20 dengan hasil yang sama. Diperoleh nilai thitung sebesar 9,906. Kemudian mencari $t_{\text {tabel }}$ dengan $\alpha=5 \%, \mathrm{dk}=33-2=$ 31, sehingga $t_{\text {tabel }}$ sebesar 1,696. Karena $t_{\text {hitung }}>$ $t_{\text {tabel }}$ berarti koefisien korelasi antara variabel (X) dan variabel (Y) signifikan.

Hasil perhitungan koefisien determinasi diperoleh sebesar 0,760. Besar pengaruhnya ditentukan oleh koefisien determinasi $r^{2}=0,760$ atau sebesar $76 \%$ adalah hasil belajar siswa yang dipengaruhi oleh faktor disiplin belajar siswa. Sedangkan $24 \%$ dipengaruhi oleh faktor-faktor lain. Berarti masih ada faktor lain selain disiplin belajar yang memengaruhi keberhasilan belajar siswa kelas III SD Negeri 002 Sungai Pinang Kota Samarinda. Namun perlu diketahui bahwa disiplin belajar tidak sepenuhnya sebagai faktor yang berpengaruh terhadap hasil belajar siswa. Hasil dari penelitian ini ada pengaruh yang signifikan antara disiplin belajar terhadap kemandirian belajar.

\section{SIMPULAN}

Berdasarkan hasil penelitian dan hasil analisis mengenai pengaruh disiplin belajar terhadap hasil belajar Bahasa Indonesia siswa Kelas III SD Negeri 002 Sungai Pinang Kota 
163 Pengaruh Disiplin Belajar terhadap Hasil Belajar Bahasa Indonesia di Sekolah Dasar- Eka Selvi Handayani, Hani Subakti

DOI : https://doi.org/10.31004/basicedu.v5i1.633

Samarinda, dapat disimpulkan bahwa nilai ratarata tingkat disiplin belajar siswa pada mata pelajaran Bahasa Indonesia di SD Negeri 002 Sungai Pinang dalam kategori sedang dengan nilai rata-rata sebesar 71,68. Sedangkan nilai rata-rata hasil belajar Bahasa Indonesia di SD Negeri 002 Sungai Pinang masuk dalam kategori sedang dengan nilai rata-rata sebesar 74,23.

Berdasarkan analisis data diketahui bahwa terdapat pengaruh disiplin belajar terhadap hasil belajar Bahasa Indonesia siswa kelas III SD Negeri 002 Sungai Pinang Kota Samarinda. Hal ini dapat diketahui dari hasil perhitungan uji hipotesis uji $\mathrm{T}$ diperoleh nilai $\mathrm{t}_{\text {hitung }}=9,906$ untuk variabel $(\mathrm{X})$ dan variabel $(\mathrm{Y})$. Kemudian mencari $t_{\text {tabel }}$ dengan $\alpha=5 \%, d k=33-2=31$, sehingga $t_{\text {tabel }}$ sebesar 1,696. Karena $t_{\text {hitung }}>t_{\text {tabel }}$ maka Ha diterima, jika Ha diterima maka terdapat pengaruh disiplin belajar terhadap hasil belajar Bahasa Indonesia siswa kelas III SD Negeri 002 Sungai Pinang. Sedangkan besar pengaruh disiplin belajar terhadap hasil belajar Bahasa Indonesia siswa kelas III SD Negeri 002 Sungai Pinang Samarinda ditentukan oleh koefisiensi determinasi $r^{2}=0,760$ atau sebesar $76 \%$.

\section{DAFTAR PUSTAKA}

Anwar \& Jaliyuddi. (2016). Pengaruh Disiplin Dalam Belajar Bahasa Indonesia Terhadap Prestasi Belajar Bahasa Indonesia Pada Siswa Kelas Viii SMP Negeri 2 Sampolawa. Edumatica 06(April): 25-36. Diakses melalui https://ejournal.undiksha.ac.id/index.php/MI/ article/download/21279/13276.

Arifin, S., Yahya, M., \& Siddik, M. (2019). Strategi Komunikasi Siswa dan Guru Kelas XI SMAN 2 Sangatta Utara dalam Proses
Pembelajaran Bahasa Indonesia. Diglosia: Jurnal Kajian Sastra, Bahasa, dan Pengajarannya, 2(1), 15-38. http://diglosiaunmul.com/index.php/diglosia/ article/view/3.

Arifin, N. (2020). Efektivitas Pembelajaran Stem Problem Based Learning Ditinjau Dari Daya Juang Dan Kemampuan Pemecahan Masalah Matematis Mahasiswa Pgsd. JPMI (Jurnal Pendidikan Matematika Indonesia) 5(1): 31. Diakses melalui https://journal.stkipsingkawang.ac.id/index.p hp/JPMI/article/view/1644/pdf.

Asrul \& Rosnita. (2014). Evaluasi Pembelajaran. Medan: Citapustaka Media.

Budiarti, I. \& A. Jabar. (2016). Pengaruh Gaya Belajar Terhadap Hasil Belajar Bahasa Indonesia Siswa Kelas VIII SMPN 2 Banjarmasin Tahun Ajaran 2015/2016. Math Didactic: Jurnal Pendidikan Bahasa Indonesia 2(3): 142-47. Diakses melalui https://media.neliti.com/media/publications/1 76870-ID-pengaruh-gaya-belajar-terhadaphasil-bel.pdf.

Ekawati, Shindy. (2016). Pengaruh Kedisiplinan Dan Aktivitas Belajar Terhadap Hasil Belajar Bahasa Indonesia Siswa. Pedagogik 1(2): 119-30. Diakses melalui https://journal.uncp.ac.id/index.php/Pedagog y/article/view/361/321.

Fahrurrozi \& Hamdi. (2017). Metode Pembelajaran Bahasa Indonesia. Sorong: Universitas Hamzanwadi Press.

Febrianti, L. \& L. Rachmawati. (2018). Pengaruh Kecerdasan Emosional Dan Disiplin Belajar Terhadap Hasil Belajar Siswa Di SMA Negeri 3 Nganjuk. Jurnal Pendidikan Ekonomi (JUPE) 6(2): 69-75. Diakses melalui https://jurnalmahasiswa.unesa.ac.id/index.ph p/jupe/article/viewFile/24429/22352.

Firmansyah, D. (2015). Pengaruh Strategi Pembelajaran dan Minat Belajar Terhadap Hasil Belajar Bahasa Indonesia. Jurnal Pendidikan Uniska 3(1): 37. Diakses melalui https://journal.unsika.ac.id/index.php/judika/ article/viewFile/199/197. 
164 Pengaruh Disiplin Belajar terhadap Hasil Belajar Bahasa Indonesia di Sekolah Dasar- Eka Selvi Handayani, Hani Subakti

DOI : https://doi.org/10.31004/basicedu.v5i1.633

Hamiyah, N. \& M. Jauhar. (2014). Strategi Belajar-Mengajar Di KELAS. Jakarta: Prestasi Pustakarya.

Heruman. (2016). MODEL PEMBELAJARAN Bahasa Indonesia DI SEKOLAH DASAR. Bandung: RAJA ROSDAKARYA.

Hamzah, A. (2014). Evaluasi Pembelajaran Bahasa Indonesia. Jakarta: Rajawali Pres.

Jamilah, N., Mulawarman, W. G., \& Hudiyono, Y. (2020). Pengembangan Bahan Ajar Interaktif 'POST' dalam Pembelajaran Apresiasi Puisi untuk Siswa Kelas X SMA. Diglosia: Jurnal Kajian Bahasa, Sastra, dan Pengajarannya, 3(1),

14-23. https://doi.org/10.30872/diglosia.v3i1.28.

Khafid, M. \& Suroso. (2007). Pengaruh Disiplin Belajar dan Lingkungan Keluarga Terhadap Hasil Belajar Ekonomi. Dinamika Pendidikan 2(2): 185-204. Diakses melalui https://journal.unnes.ac.id/nju/index.php/DP/ article/view/447.

Navia, Y. \& P. Yulia. (2017). Hubungan Disiplin Belajar Dan Konsentrasi Belajar Terhadap Hasil Belajar Bahasa Indonesia Siswa. PYTHAGORAS: Jurnal Program Studi Pendidikan Bahasa Indonesia 6(2): 100-105. Diakses melalui https://www.journal.unrika.ac.id/index.php/ju rnalphythagoras/article/view/905.

Masitoh \& Habudin. (2018). Pengembangan Media Pembelajaran Papan Berpaku Untuk Meningkatkan Pemahaman Konsep Luas Bangun Datar. Ibtida'i 5(1) Diakses melalui http://jurnal.uinbanten.ac.id/index.php/ibtidai /article/view/1318/1045.

Purwanto. (2014). Evaluasi Hasil Belajar. Yogyakarta: Pustaka Belajar.

Riduwan. (2003). Dasar-Dasar Statistika. Bandung: Alfabeta Rusman. (2016). PEMBELAJARAN TEMATIK TERPADU Teori Praktik Dan Penilaian. Jakarta: Rajawali Pres.

Rusman. 2016. PEMBELAJARAN TEMATIK TERPADU Teori Praktik Dan Penilaian. Jakarta: Rajawali Pres.

Setyaningrum, I. (2011). Hubungan disiplin belajar dan motivasi belajar dengan hasil belajar IPA siswa kelas V SD negeri Gugus Lokantara Kecamtan temanggung Kabupaten Temanggung Semester 1 Tahun Pelajaran 2011/2012. Skripsi. Salatiga: Fakultas Keguruan dan Ilmu Pendidikan. Universitas Kristen Satya Wacana. Dikses melalui https://repository.uksw.edu/handle/12345678 9/1052.

Siregar, S. (2013). METODE PENELITIAN KUANTITATIF: Dilengkapi Dengan Perbandingan Perhitungan Manual\&SPSS. Jakarta: Kencana.

Subakti, Hani. (2019). 8 Konsepsi Landasan Bahasa Indonesia di Perguruan Tinggi. Parepare: Kaaffah Learning Center.

Subakti, Hani. (2019). 2 Jurus Jitu Menulis Tugas Akhir dan Skripsi. Banyumas: Pena Persada.

Sudjana. (2016). Metoda Statistika. Bandung: Tarsito.

Sugiarto, dkk,. (2019). Faktor Kedisiplinan Belajar Pada Siswa Kelas X Smk Larenda Brebes. Jurnal Mimbar Ilmu 24(2): 232-38. Diakses melalui

https://ejournal.undiksha.ac.id/index.php/MI/ article/download/21279/13276.

Sugiyono. (2007). Statistika Untuk Penelitian. Bandung: Alfabeta.

(2010). Metode Penelitian Pendidikan Pendekatan Kuantitatif, Kualitatif, Dan $R \& D$. Bandung: Alfabeta.

. (2018). Metode Penelitian Kuantitatif, Kualitatif, Dan R\&D. Bandung: Alfabeta.

Sukardi. (2015). Metodologi Penelitian Pendidikan. Jakarta: Bumi Aksara.

Sundayana, Rostina. 2013. MEDIA PEMBELAJARAN Bahasa Indonesia (Untuk Guru, Calon Guru, Orang Tua, Dan Para Pecinta Bahasa Indonesia). Bandung: Alfabeta.

Usman \& Akbar. (2009). Metode Penelitian Sosial. Jakarta: Bumi Aksara. 